\title{
Analiza zależności kształtowo-wymiarowych zgrzein garbowych w elementach przeniesienia napędu wykonanych technologią MIAB
}

\author{
Profile - dimension analysis of projection welds in transmission \\ shafts made by magnetically impelled arc butt (MIAB)
}

\section{Streszczenie}

W artykule przedstawiono wyniki symulacji numerycznych i badań eksperymentalnych połączeń garbowych typu rurablacha, występujących w układzie przeniesienia napędu pojazdu samochodowego. Zbadano wpływ materiału oraz geometrii garbu (jego średnicy, głębokości przetłoczenia i grubości blachy w miejscu garbu) na mechanizm tworzenia połączenia, w aspekcie zastosowanych parametrów procesu. Wyniki analizy numerycznej potwierdzono przeprowadzając badania makroskopowe. W toku przeprowadzonych prac stwierdzono, iż dla połączenia, w którym grubość blachy oraz głębokość przetłoczenia garbu jest mniejsza, powstaje zgrzeina pierścieniowa, którą wyeliminować można poprzez zastosowanie programu zgrzewania typu "slope" - z proporcjonalnym narastaniem prądu zgrzewania. Wykorzystanie programu "slope" oraz zmiana geometrii garbu umożliwiło uzyskanie prawidłowej zgrzeiny na całej powierzchni garbu.

Słowa kluczowe: zgrzewanie łukiem wirującym; optymalizacja procesu zgrzewania garbowego; modelowanie MES procesu zgrzewania

\begin{abstract}
The article presents the results of numerical simulations and experimental research of projection welds made with using tube and plate, occurring in the transmission shaft of a motor vehicle. The effect of the material type and the geometry of the projection (the diameter, depth and thickness of the punch indentation) on the mechanism of formation of the connection, in the relation with the process parameters was examined. The results of numerical analysis was confirmed by metallography macro tests. It was found that for the connection, wherein the thickness of the steel plate and the depth of the punch indentation is lower the adverse circularshape weld is formed which can be avoided by the application of "slope program" - with proportional increasing rate of current. Using of the "slope program" and modification of projection geometry allows to obtain the proper shape of projection weld.
\end{abstract}

Keywords: magnetically impelled arc butt; optimization of projection welding process; numerical modelling o resistance welding process

\begin{abstract}
Wstęp
Problematyka wyważania układów przeniesienia napędu Wały przegubowe wytwarzane technologią zgrzewania łukiem wirującym, będące przedmiotem niniejszego opracowania są elementami konstrukcji, których zadaniem jest przeniesienie momentu obrotowego z wału wyjściowego skrzyni biegów do dyferencjału. Z uwagi na ich ciągłą pracę w warunkach zmiennych obciążeń dynamicznych, zrównoważenie momentu obrotowego na całej długości wału jest istotnym zagadnieniem, które nie może zostać pominięte na etapie produkcji. Niepożądanym efektem niezrównoważenia jest efekt tzw. „bicia”, który przyczynia się do dyskomfortu użytkownika podczas podróży, wynikającego z odczuwalnych wibracji oraz nadmiernego hałasu [1]. Dla samego wału (często składającego się z kilku sekcji) konsekwencje
\end{abstract}

nierównomiernie rozłożonego momentu obrotowego mogą być dużo poważniejsze i skutkować uszkodzeniem łożysk, przegubów, wielowypustów, a w skrajnym przypadku prowadzą do całkowitego zniszczenia całego wału przegubowego i elementów z nim powiązanych (np. skrzynia biegów, mechanizm różnicowy).

Niewyważenie wałów przegubowych na wyjściu linii produkcyjnej po procesie zgrzewania łukiem wirującym jest spowodowane przez:

- znaczną (w zależności od rozwiązania konstrukcyjnego 2 - 3,5m) długość elementu,

- odchyłki wymiarowo-kształtowe zgrzewanych podzespotów dostarczanych przez poddostawców (przeguby, rury),

- odchyłki w procesach obróbki skrawaniem oraz w procesie MIAB (np. nieregularna wypływka).

Widok przykładowego, kompletnego wału napędowego, składającego się z 3 sekcji przedstawiono na rysunku 1.

Dr inż. Marcin Korzeniowski, dr inż.Tomasz Piwowarczyk, dr inż. Paweł Kustroń, prof. dr hab. dr inż. Andrzej Ambroziak - Politechnika Wrocławska; dr inż. Zygmunt Mikno - Instytut Spawalnictwa, Gliwice; inż. Maciej Kozioł, inż. Sławomir Krzywański, mgr inż. Dariusz Jabłoński - GKN Driveline Oleśnica.

Autor korespondencyjny/Corresponding author. marcin.korzeniowski@pwr.edu.pl 


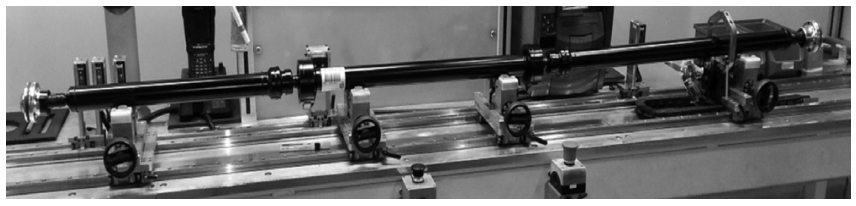

Rys. 1. Wał napędowy składający się z 3 sekcji na stanowisku do pomiarów geometrycznych

Fig. 1. The drive shaft consisted of 3 sections on the geometrical measurements setup

W warunkach produkcyjnych, w celu kompensacji nierównomiernie rozłożonego momentu obrotowego, bezpośrednio po procesie zgrzewania łukiem wirującym kompletny wał napędowy poddawany jest testowi polegającemu na wyznaczeniu stopnia jego niewyważenia. Pomiar ten odbywa się na tzw. wyważarce, zintegrowanej ze zgrzewarką rezystancyjną garbową (rys. 2), która służy do przygrzania stalowych odważników, mających na celu zrównoważenie momentu na całym obwodzie wału. Proces wyważania przebiega w 3 etapach.

1. W pierwszej kolejności wyznaczany jest stopień niewyważenia oraz miejsce wystąpienia największego bicia. $\mathrm{Na}$ obu końcach wał jest mocowany w trójszczękowych uchwytach, a następnie rozpędzany do zadanej prędkości obrotowej. Po zatrzymaniu wału w wyznaczonej pozycji, system informuje o stopniu niewyważenia, a na panelu operatorskim wskazywany jest rodzaj odważnika (jego masa), którą operator musi użyć aby operacja wyważania przebiegła prawidłowo.

2. Kolejnym etapem jest proces zgrzewania garbowego, który polega na montażu odważnika w oprzyrządowaniu, a następnie automatyczne zgrzanie odważnika z rurą. Miejsce przygrzania odważnika, podobnie jak dobór jego masy jest wyznaczane w sposób automatyczny. Masy odważników stopniowane co jeden gram w zakresie od 2 - 20 gramów. W przypadku niewyważenia wału, wymagającego większej masy odważnika, element taki uznaje się za wadliwy i przeznaczony do złomowania.

3. Gdy proces zgrzewania jest zakończony następuje ponowny test, sprawdzający nierównomierność bicia. Jeżeli moment obrotowy mieści się w zakresie zadanej tolerancji kompletny wał jest przekazywany na kolejne elementy linii montażowej. W przeciwnym wypadku wyznaczana jest masa kolejnego odważnika i miejsce jego zgrzewania. Należy podkreślić, iż pomimo tego, że standardy produkcyjne dopuszczają taką możliwość, najczęściej praktykowanym sposobem równoważenia nierównomierności bicia wału jest zgrzewanie tylko jednego odważnika na jednej płaszczyźnie korekcyjnej.
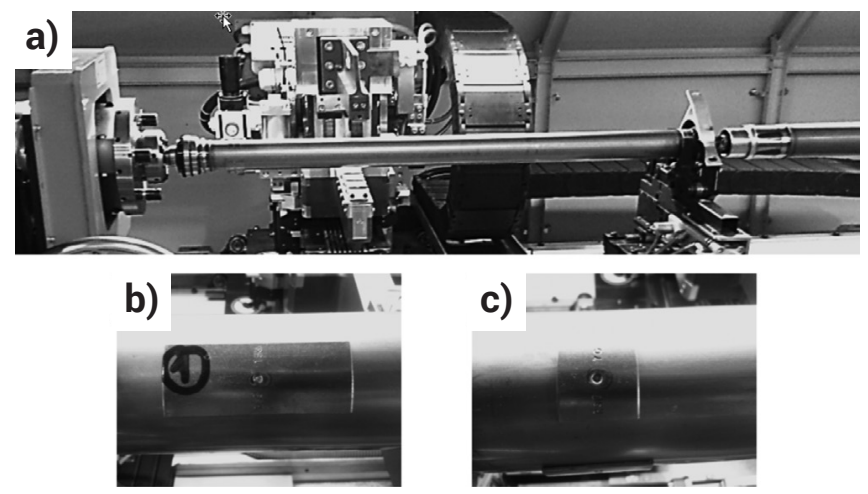

Rys. 2. Wyważarka wału napędowego zintegrowana ze zgrzewarką garbową (a), odważniki (b,c)

Fig. 2. Balancing the drive shaft machine coupled with projection welding gun $(a)$, weights $(b, c)$
Oprzyrządowanie zintegrowanej z wyważarką zgrzewarki garbowej dedykowane jest do zgrzewania wału napędowego, na którego podstawowe części składają się przegub, rura i końcówka osi tzw. „stubshaft". Widok części roboczych wyważarki z zintegrowaną zgrzewarką garbową oraz typowe odważniki dogrzewane do wału przedstawiono na rysunku 2.

\section{Technologia zgrzewania garbowego - materiały zgrzewane i parametry zgrzewania}

Odważniki, służące jaklo elementy równoważące moment obrotowy podczas pracy wału posiadają przetłoczone garby, których geometria jest zgodna z wytycznymi PN-EN 28167:2002 [2].

Na rysunku 3 przedstawiono schemat garbu z jego wymiarami charakterystycznymi (dla stali o grubości do $3 \mathrm{~mm}$ ), a w tablicy I zamieszczono odpowiadające im wartości [2]. Wymiary charakterystyczne garbów to: średnica $\left(\Phi d_{1}\right)$ i wysokość garbu (a) - obie wielkości mierzone są w stosunku do powierzchni blachy od strony matrycy, oraz średnica wewnętrznej części garbu $\left(\Phi d_{2}\right)$.

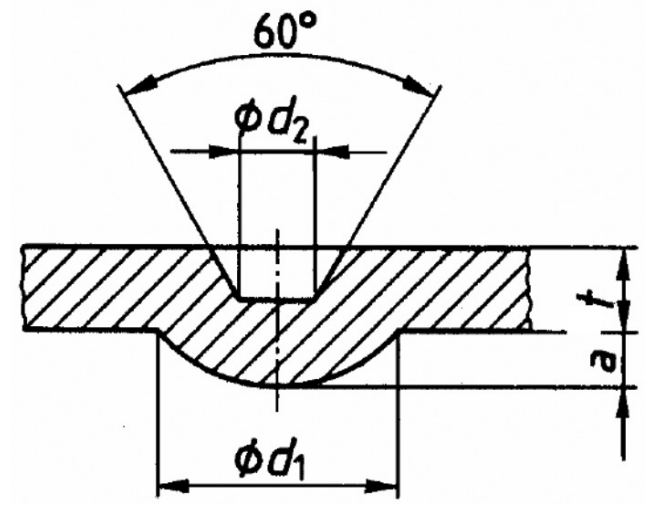

Rys. 3. Wymiary charakterystyczne garbu wg PN-EN 28167:2002 [2] Fig. 3. Dimensions of projections according to PN-EN 28167:2002 [2]

Tablica I. Wartości wymiarów charakterystycznych garbów wg PN-EN 28167:2002 (wszystkie wymiany w $\mathrm{mm}$ ) [2]

Table I. The values of the characteristic dimensions of projections according to PN-EN 28167:2002 (in $\mathrm{mm}$ ) [2]

\begin{tabular}{|c|c|c|}
\hline $\mathbf{d}_{\mathbf{1}}$ & $\mathbf{a}$ & $\mathbf{d}_{\mathbf{2}}$ \\
\hline 1.6 & 0.4 & 0.5 \\
2.0 & 0.5 & 0.63 \\
2.5 & 0.63 & 0.8 \\
3.2 & 0.8 & 1.0 \\
4.0 & 1.0 & 1.25 \\
5.0 & 1.25 & 1.6 \\
6.3 & 1.6 & 2.0 \\
8.0 & 2.0 & 2.5 \\
10.0 & 2.5 & 3.2 \\
\hline
\end{tabular}

W procesie produkcyjnym wałów napędowych wykorzystywane są 2 rodzaje odważników, różniących się od siebie geometrią garbów oraz składem chemicznym. Składy chemiczne materiałów 1 i 2 odpowiadają głębokotłocznym stalom niestopowym DC04 i DC01. Widok garbów wykonanych na odważnikach przedstawiono na rysunku 4, natomiast odpowiadające im składy chemiczne w tablicy II. Rura, do której dogrzewane są garby wykonana jest ze stali C22 (DIN 17204). Jest to stal przeznaczona do utwardzania powierzchniowego i ulepszania cieplnego. Skład chemiczny materiału rury zamieszczono $\mathrm{w}$ tabeli II. 
Tablica II. Składy chemiczne materiałów zgrzewanych (odważniki, rura)

Table II. The chemical compositions of materials to be welded (weights, pipe)

\begin{tabular}{|c|c|c|c|c|c|c|c|c|}
\hline Materiał & \multicolumn{9}{|c|}{ Skład chemiczny [\% wag.] } \\
\hline & $\mathrm{C}$ & $\mathrm{Mn}$ & $\mathrm{Si}$ & $\mathrm{P}$ & $\mathrm{S}$ & $\mathrm{Al}$ & $\mathrm{Cr}$ & $\mathrm{Ni}$ \\
\hline Odważnik 1 (DC04) & 0,028 & 0,19 & 0,015 & 0,011 & 0,004 & 0,041 & 0,030 & 0,051 \\
\hline Odważnik 2 (DC01) & 0,044 & 0,23 & 0,011 & 0,015 & 0,012 & 0,028 & 0,017 & 0,020 \\
\hline Rura (C22) & 0,220 & 0,680 & 0,070 & 0,010 & 0,003 & 0,037 & - & - \\
\hline
\end{tabular}
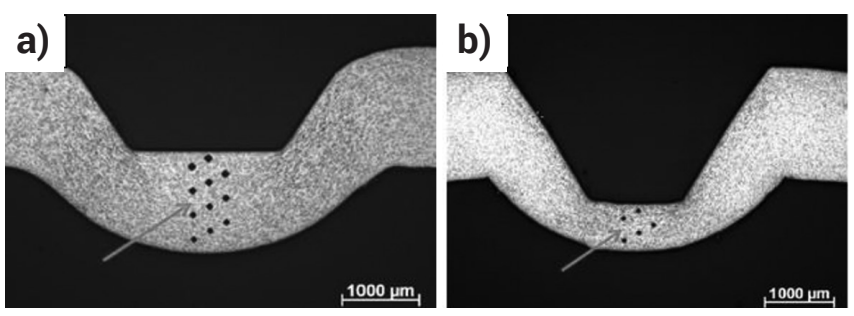

Rys. 4. Widok garbów wykonanych na odważnikach ze stali: DC04 (a), DC01 (b)

Fig. 4. Projections in the weights made of DCO4 (a) and DC01 (b) mild steel

Pomimo zgodności wymiarów garbów z wytycznymi PN-EN 28167:2002, wyraźnie widoczne są różnice w geometrii i kształcie garbów. W stosunku do garbu wykonanego w odważniku ze stali DC04, garb wykonany w stali DC01 charakteryzuje się większym przetłoczeniem od strony stempla oraz znacznie mniejszą grubością ścianki - zarówno w bocznej jego części, jak i centralnej części przetłoczenia.

Analiza składu chemicznego zarówno odważników jak i rury wskazuje, że wszystkie materiały należą do grupy stali łatwo spawalnych, stąd nawet pomimo znacznych różnic w składzie - szczególnie zawartości węgla i manganu, z metalurgicznego punktu widzenia nie należy spodziewać się problemów z uzyskaniem prawidłowego złącza zgrzewanego.

Układ zasilania zgrzewadła składa się z inwertora średniej częstotliwości z prostowaniem po stronie wtórnej transformatora, z układem sterowania i stabilizacji prądu zgrzewania. Proces zgrzewania polegał na zastosowaniu programu prostego, którego parametry przedstawiały się następująco:

- czas docisku wstępnego, $\mathrm{t}_{\mathrm{w}}=800 \mathrm{~ms}$,

- czas zgrzewania, $\mathrm{t}_{\mathrm{z}}=60 \mathrm{~ms}$,

- natężenie prądu zgrzewania, $\mathrm{l}_{\mathrm{z}}=9,5 \mathrm{kA}$,

- czas docisku końcowego, $t_{k}=400 \mathrm{~ms}$,

- siła docisku elektrod $F_{d}=1300 \mathrm{~N}$.

Prąd zgrzewania doprowadzany był do obszaru złącza za pośrednictwem elektrod, które od strony rury stanowił odpowiednio profilowany płaskownik ze stopu miedzi klasy A2, a od strony odważnika nasadka typu C (wg ISO 5821:2010 [3]) o średnicy $\mathrm{d}=16 \mathrm{~mm}$.

\section{Problematyka zgrzewania odważników z różnych gatunków stali}

Przeprowadzane wyrywkowo w procesie poprodukcyjnym badania metalograficzne makro- i mikroskopowe połączeń zgrzewanych odważników z rurą wykazały, że dla części zgrzein wykonanych z wykorzystaniem odważników ze stali DC01 otrzymana zgrzeina nie miała na całym przekroju charakteru ciągłego, wykazując cechy zgrzein pierścieniowych (rys. 5a) i na podstawie wytycznych i norm zakładowych [4] nie mogła zostać zakwalifikowana jako zgrzeina prawidłowa. Połączenie uzyskane z użyciem odważnika ze stali DC04 (rys. 5b) było w 100\% zgodne z obowiązującymi normami. Dalszej analizie i próbie optymalizacji procesu zgrzewania poddano wyłącznie połączenie z wykorzystaniem odważników ze stali DC01.
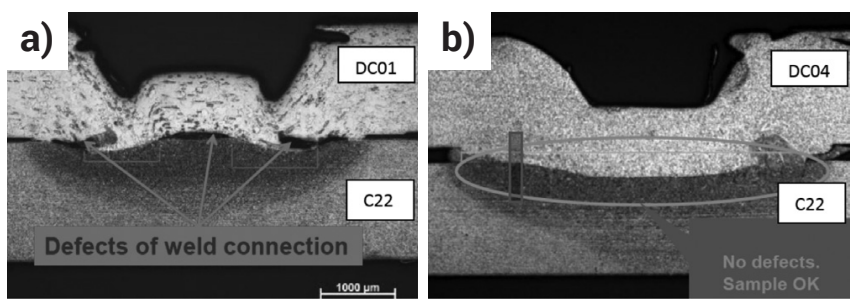

Rys. 5. Widok makrostruktury połączenia z wykorzystaniem odważnika ze stali DC01 (a) i stali DC04 (b) zgrzewanych prostym programem zgrzewania

Fig. 5. Macrostructure of the joints with using the weight of steel DC01 (a) and DC04 (b) welded with simple welding programme

$\mathrm{Na}$ rysunku 6 przedstawiono wynik symulacji numerycznych przeprowadzonych w programie SORPAS, dedykowanym do analizy procesu zgrzewania rezystancyjnego, w tym garbowego [5:7]. Jako dane wejściowe wykorzystano program i parametry zgrzewania, dane materiałowe oraz geometrie garbów, występujące w rzeczywistym procesie zgrzewania.
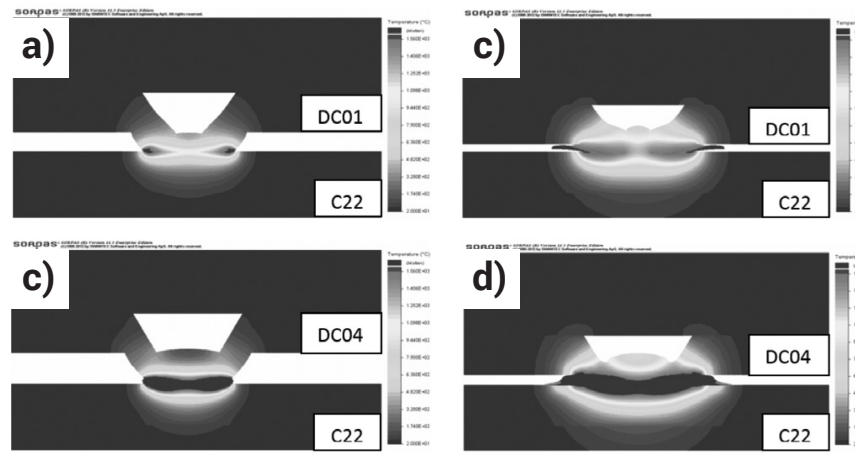

Rys. 6. Wyniki symulacji numerycznych procesu zgrzewania rezystancyjnego garbowego odważnika ze stali DC01 (a,b) i DC04 (c,d) z zastosowaniem prostego programu zgrzewania na różnym etapie tworzenia połączenia: w 20 ms $(a, c)$ i 60 ms (b,d) przepływu prądu zgrzewania

Fig. 6. The results of numerical simulations of the projection resistance welding process of the weight of DC01 $(a, b)$ and DC04 (c,d) steel using a simple program welding at different stages of creating a welding joint: $20 \mathrm{~ms}(\mathrm{a}, \mathrm{c})$ and $60 \mathrm{~ms}(\mathrm{~b}, \mathrm{~d})$ of welding current flow

Stal DC01, z której wykonywane są odważniki zalicza się grupy stali bardzo dobrze spawalnych, z tego względu własności materiałowe jako źródło powstawania niezgodności zilustrowanej na rysunku 5 a zostały wykluczone, a proces optymalizacji ukierunkowano na dwa aspekty: modyfikację programu i parametrów zgrzewania oraz zmianę geometrii garbu, zbliżoną do garbu wykonanego w materiale ze stali DC04. 


\section{Modyfikacja programu zgrzewania}

Symulacje numeryczne potwierdziły, że mechanizm tworzenia zgrzeiny garbowej odważnika ze stali DC01 z rurą przy zastosowaniu programu prostego zgrzewania jest źródłem niezgodności w złączu Relatywnie szybkie nagrzewanie styku centralnego przy równoczesnym działaniu siły docisku powoduje jego gwałtowne odkształcenie i utworzenie kontaktu o zbyt dużej powierzchni. Duża powierzchnia styku powoduje spadek gęstości prądu, co prowadzi do stapiania tylko zewnętrznych obszarów styku elementów zgrzewanych. Przepływający przez obszar styku prąd elektryczny generuje ciepło w zewnętrznych obszarach, które determinuje tworzenie zgrzeiny pierścieniowej. W celu dokładnej kontroli mechanizmu odkształcania styku centralnego zdecydowano się na zastosowanie programu zgrzewania złożonego z dwóch etapów przepływu prądu:

- liniowego narastania prądu zgrzewania przez pierwszą część jego przepływu,

- stały przepływ prądu w drugiej części przepływu prądu.

Czas narastania prądu zgrzewania od wartości $0-9,5 \mathrm{kA}$ dobrano tak, aby energia dostarczona do miejsca zgrzewania była w przybliżeniu taka sama, jak podczas zastosowania programu prostego.

Na rysunku 7 w schematyczny sposób przedstawiono zastosowany tzw. program „up-slope" z liniowym narastaniem prądu zgrzewania.

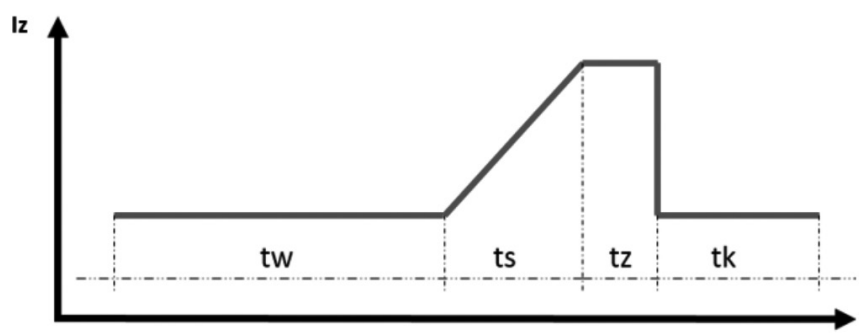

Rys. 7. Schemat programu „up-slope” z liniowym narastaniem prądu zgrzewania

Fig. 7. Outline of linear up-slope welding current program
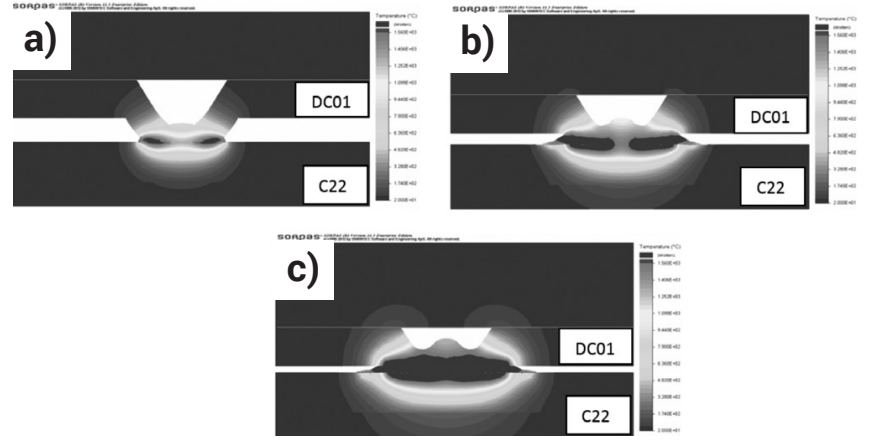

Rys. 8. Wyniki symulacji numerycznych procesu zgrzewania rezystancyjnego garbowego odważnika ze stali DC01 z zastosowaniem programu „up-slope” na różnym etapie procesu: w 20 ms (a), 60 ms (b) i 90 ms (c) przepływu prądu zgrzewania

Fig. 8. Results of numerical simulations of projection resistance welding process of weight made of DC01 steel using the up-slope program at different stages of the process: $20 \mathrm{~ms}$ (a), $60 \mathrm{~ms}$ (b) and $90 \mathrm{~ms}(\mathrm{c})$ of the welding current flow

Parametry programu zgrzewania, składającego się z liniowego narastania prądu wynosiły odpowiednio:

- czas docisku wstępnego, tw $=800$ ms,

- czas narastania prądu zgrzewania w zakresie 0 - 9,5kA, ts $=60 \mathrm{~ms}$,

- czas przepływu prądu o stałej wartości natężenia, $\mathrm{t}_{\mathrm{z}}=30 \mathrm{~ms}$,
- natężenie prądu zgrzewania, $\mathrm{I}_{\mathrm{z}}=9,5 \mathrm{kA}$,

- czas docisku końcowego, $\mathrm{t}_{\mathrm{k}}=400 \mathrm{~ms}$,

- siła docisku elektrod $F_{d}=1300 \mathrm{~N}$.

Testy praktyczne na stanowisku zgrzewalniczym z zastosowaniem programu "up-slope" poprzedzono badaniami symulacyjnymi, których wyniki zaprezentowano na rysunku 8. Jako dane wejściowe wprowadzono parametry zgrzewania przedstawione powyżej.

Przeprowadzone symulacje numeryczne wskazują, iż dzięki zmianie programu zgrzewania na tzw. „up-slope” (program z liniowym narastaniam natężenia prądu zgrzewania) możliwe jest uzyskanie ciągłego połączenia na całym przekroju zgrzeiny garbowej. Analizując poszczególne etapy tworzenia zgrzeiny zaobserwować można dokładnie mechanizm jej powstawania. W początkowej fazie procesu tworzy się zgrzeina pierścieniowa, styk centralny ulega odkształceniom, podobnie jak w przypadku programu prostego. Powolne narastanie prądu zgrzewania powoduje jednak znacznie wolniejsze odkształcanie styku centralnego, przez co możliwe jest przekazywanie ciepła do środkowej części garbu tak, że w końcowej fazie procesu zgrzeina obejmuje cały przekrój garbu.

Obiecujące wyniki symulacji numerycznych stanowiły podstawę wdrożenia programu złożonego do wykonania połączeń testowych odważników ze stali DC01 z rurą ze stali C22. Na rysunku 9 przedstawiono wynik badania makroskopowego połączenia z zastosowaniem programu złożonego, z narastaniem liniowym natężenia prądu zgrzewania.

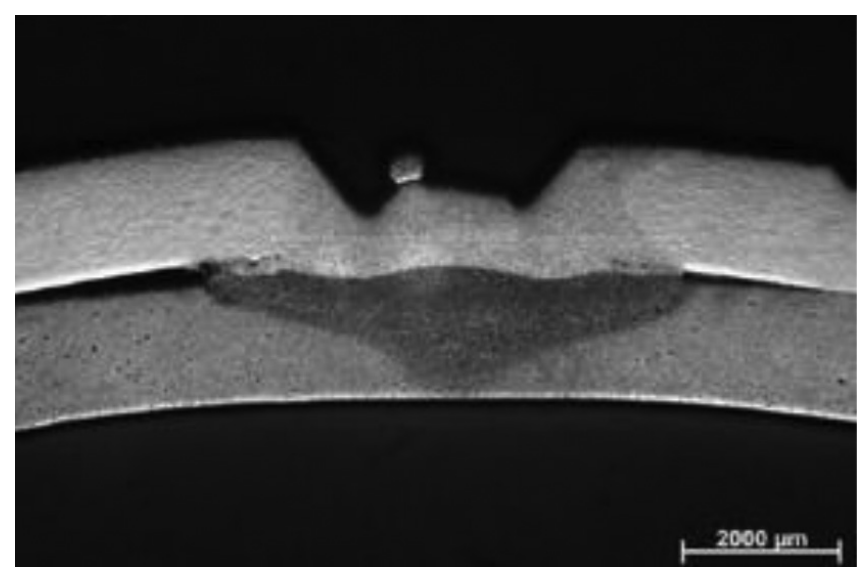

Rys. 9. Widok makrostruktury połączenia z wykorzystaniem odważnika ze stali DC01 zgrzewanego złożonym programem (liniowe narastanie prądu zgrzewania)

Fig. 9. Macrostructure of projection welding joint of weight made of DC01 complex welding program (welding current linear up-slope)

Przeprowadzone testy praktyczne w warunkach przemysłowych $\mathrm{w}$ pełni potwierdziły obliczenia numeryczne przeprowadzone w programie SORPAS. Złącze przedstawione na rys. 9 charakteryzuje się ciągłością na całym przekroju i kwalifikuje się jako połączenie poprawne.
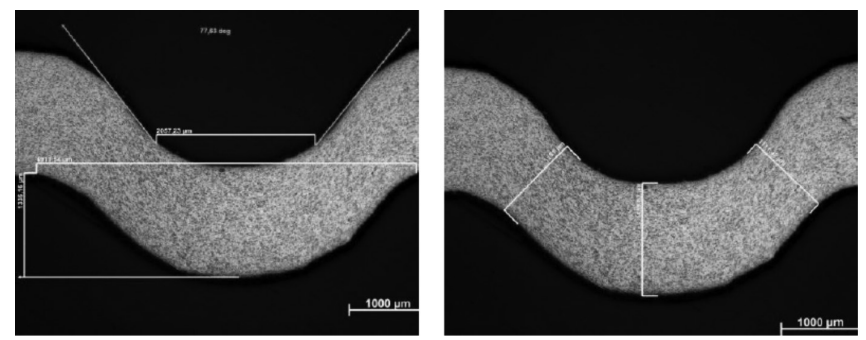

Rys. 10. Widok garbów w odważniku ze stali DC01 wytworzonych poprzez zastosowanie opracowanego zestawu stempel-matryca Fig. 10. Projections in weights made of DC01 steel produced with using developed set of punch-die 
Odważniki o geometrii garbów przedstawionej na rysunku 10. zostały wykorzystanie do testów zgrzewania przy użyciu prostego programu zgrzewania. Na rysunku 11. przedstawiono wyniki symulacji numerycznych oraz widok badań makroskopowych otrzymanych połączeń.

\section{Dyskusja wyników}

Pomimo wykorzystania łatwo zgrzewalnych stali głębokotłocznych z grupy DC, oraz stosowania wytycznych PN-EN 28167:2002 odnośnie geometrii garbów, proces zgrzewania odważników przebiega w sposób uniemożliwiający zakwalifikowanie połączeń jako prawidłowych, gdyż nie spełniają one ustalonych przez koncern produkujący półosie oczekiwań. Występujące w procesie zgrzewania wady zakwalifikować można jako przyklejenie lub pustkę w środku zgrzein pierścieniowych (niezgodność nr 4.5 wg PN-EN ISO 6520-2:2013 [4]), które relatywnie często występują podczas zgrzewania garbowego blach $[8,9]$. Przeprowadzone symulacje numeryczne oraz badania makroskopowe wskazują, że przyczyną powstawania zgrzein pierścieniowych może być zbyt szybkie odkształcanie się części centralnej garbu, nie w wyniku uplastycznienia wynikającego z nagrzewania, lecz poprzez działanie siły docisku, która powoduje odkształcenie centralnej jego części w kierunku przeciwnym do działającej siły. Zjawisko to występuje tylko dla odważnika ze stali DC01, którego garb charakteryzuje się mniejszą o ok. $80 \%$ grubością ścianki w miejscu garbu. Zwiększa to tendencję do jego niewłaściwego odkształcania podczas procesu zgrzewania. Zastosowanie programu z liniowym narastaniem natężenia prądu zgrzewania zwiększa tendencję garbu do odkształcenia plastycznego w wyniku temperatury, a w związku z tym maleje skłonność do niekontrolowanej zmiany jego geometrii. To niekorzystne zjawisko można całkowicie wyeliminować poprzez zmianę wymiarów i kształtu garbów tj. użycie takiej kombinacji stempel - matryca aby zwiększyć grubość ścianki w odważniku. Należy podkreślić, że grubość ścianki w miejscu garbu jest parametrem, który nie jest przytaczany w PN-EN 28167:2002 dotyczącej projektowania geometrii garbów. Przeprowadzona analiza numeryczna i badania eksperymentalne wskazują, że jest ona istotnym parametrem, od którego w dużym stopniu zależy mechanizm tworzenia połączenia garbowego.
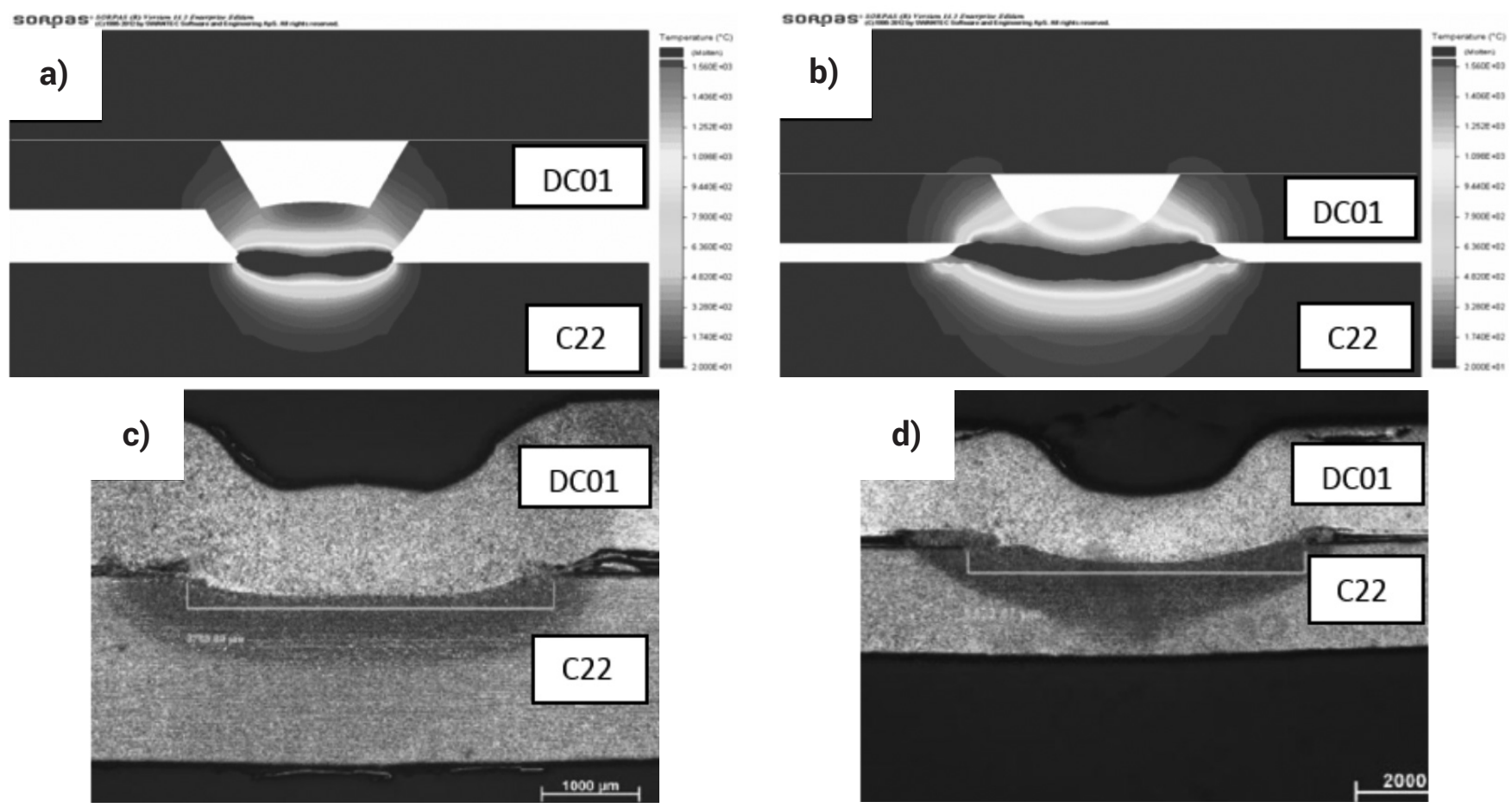

Rys. 11. Wyniki symulacji numerycznych procesu zgrzewania rezystancyjnego garbowego odważnika ze stali DC01 ze zmodyfikowaną geometrią garbu na różnym etapie tworzenia połączenia przy wykorzystaniu programu prostego w 20 ms (a) i 60 ms (b) przepływu prądu zgrzewania, oraz widok makrostruktury rzeczywistych złączy $(c, d)$

Fig. 11. Results of numerical simulations of projection resistance welding process of weight made of DC01 steel with a modified geometry of the projection at different stages of joint creating, using a simple program $20 \mathrm{~ms}$ (a) and $60 \mathrm{~ms}$ (b) of the welding current flow, macrostructure of joints to be welded (c,d)

\section{Wnioski}

W wyniku przeprowadzonych analiz numerycznych i badań eksperymentalnych sformułowano następujące wnioski poznawcze:

- użycie garbu spełniającego wymogi PN-EN 28167:2002 nie gwarantuje uzyskania zgrzeiny na całym przekroju, a w większości przypadków powoduje powstanie zgrzeiny pierścieniowej z pustką lub przyklejeniem w miejscu styku centralnego,

- przyczyną powstawania zgrzein pierścieniowych jest głównie geometria garbu, tj., grubość ścianki bocznej garbu i dna,

- zmiana parametrów zgrzewania nie zmienia mechanizmu powstawania połączenia, aczkolwiek zauważalna jest jego ciągłość, uwidoczniona podczas badań makroskopowych, 
- najprostszym i najskuteczniejszym rozwiązaniem okazała się zmiana geometrii garbu, w taki sposób aby grubość ścianki wynosiła co najmniej $1,1 \mathrm{~mm}$.

Badania zostały przeprowadzone w ramach projektu pt. „Kryteria i metodyka określania jakości złączy zgrzewanych łukiem wirującym " finansowanym przez Narodowe Centrum Badań i Rozwoju w ramach III Programu Badań Stosowanych.

\section{Literatura}

[1] Piwowarczyk T., Korzeniowski M., Ambroziak A., Rutka R., Krzywański S., Karolewski M.: Ocena jakości komponentów zgrzewanych łukiem wirującym, Przegląd Spawalnictwa, nr ? 2016,

[2] PN-EN 28167:2002: Garby do zgrzewania rezystancyjnego,

[3] PN-EN ISO 5821:2010: Zgrzewanie rezystancyjne - Nasadki elektrod do zgrzewania punktowego,

[4] PN-EN-ISO 6520-2:2013, Spawanie i procesy pokrewne - Klasyfikacja geometrycznych niezgodnościspawalniczych w metalach - Część 2: Zgrzewanie,

[5] Mikno Z., Kowieski Sz., Bartnik Z, Derlukiewicz W.,: Zgrzewanie garbowe w obliczeniach metodą elementów skończonych, Przegląd Spawalnictwa, nr 11 2015,

[6] Nielsen Ch. V., Zhang W., Martins P. A.F., Baya N.: Numerical and Experimental Analysis of Resistance Projection Welding of Square Nuts to Sheets, Procedia Engineering, Vol. 81, 2014,

[7] Zhu, W.F., Lin Z.-Q., Lai X.-M., Luo A.H.: Numerical analysis of projection welding on auto-body sheet metal using a coupled finite element method, International Journal of Advanced Manufacturing Technology no. 1, 2006,

[8] Papkala H.: Zgrzewanie oporowe metali, Kabe, Krosno 2003,

[9] Czuchryj J., Papkala H., Winiowski A.: Niezgodności w złączach spawanych, Instytut Spawalnictwa w Gliwicach, Gliwice 2005. 